Jurnal At-Tibyan: Jurnal Ilmu Alqur'an dan Tafsir Volume 6 No. 2, Desember 2021 (p. 243-266)

P ISSN 2442-594X | E ISSN 2579-5708

http://journal.iainlangsa.ac.id/index.php/tibyan

\title{
THE VERNACULARITY IN THE TAFSİRIYAH TRANSLATION OF NADOMAN NURUL HIKMAH
}

\author{
Ahmad Rifqi Muchtar \\ Universitas Islam Negeri Syarif Hidayatullah Jakarta, Indonesia \\ arifqimuchtar@uinjkt.ac.id \\ Mariya Luthfiana \\ Pondok Pesantren Al-Barokah Tasikmalaya, Indonesia \\ mariyaluthfiana28@gmail.com \\ DOI 10.32505/at-tibyan.v6i2.3261 \\ \begin{tabular}{|l|l|l|}
\hline Submitted: 08-09-2021 & Revised: 02-12-2021 & Accepted: 22-12-2021 \\
\hline
\end{tabular}
}

\begin{abstract}
The vernacularity of the poetic translation of the Qur'an Nadoman Nurul Hikmah by Hidayat Suryalaga lies in its peculiarity in using the language and rules of Sundanese poetry of praise. This paper aims to explain the form of vernacularity in the translation of Nadoman Nurul Hikmah's interpretation by H. R. Hidayat Suryalaga. This article uses descriptive methods and content analysis, thus concluding that the aspect of nadoman content or the meaning of the verses in Nadoman Nurul Hikmah is far more accurately called a translation of tafsiriyah al-Qur'an than it is called poetic interpretation of the Qur'an. H. R. Hidayat Suryalaga, in Nadoman Nurul Hikmah, does not at all refer to the Arabic translation or interpretation in each stanza. H. R. Hidayat Suryalaga did not use the verse editor as a source, but he tried to provide his interpretation. Meanwhile, in Nadoman, Nurul Hikmah does the loose and contextual translation. The contextualization of the verses of the Qur'an gives the impression to the readers (singers) of Nadoman that Nadoman Nurul Hikmah can be enjoyed by anyone who is by the spirit of the times.
\end{abstract}

Keywords: Vernacularity, Nadoman, Tafsiriyah Translation, Praise

\begin{abstract}
Abstrak
Bentuk vernakularitas terjemahan puitis al-Qur'an Nadoman Nurul Hikmah karya Hidayat Suryalaga terletak pada kekhasannya menggunakan bahasa dan kaidah-kaidah pupujian puisi Sunda. Tulisan ini bertujuan menjelaskan bentuk vernakularitas pada terjemah tafsiriyah Nadoman Nurul Hikmah karya H. R. Hidayat Suryalaga. Artikel ini menggunakan metode deskriftif dan analisis isi, sehingga menemukan kesimpulan bahwa aspek konten (isi) nadoman atau
\end{abstract}

Copyright @ 2021. Owned by the Author, published by Jurnal At-Tibyan: Jurnal Ilmu Alqur'an dan Tafsir. Articles with open access. License: CC-BY

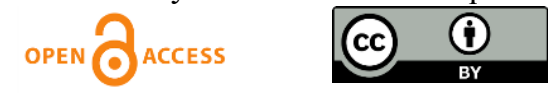


kandungan makna ayat dalam Nadoman Nurul Hikmah jauh lebih tepat disebut terjemah tafsiriyah al-Qur'an daripada disebut puitisasi tafsir alQur'an. H. R. Hidayat Suryalaga, dalam Nadoman Nurul Hikmah sama sekali tidak merujuk kepada terjemah atau tafsir yang berbahasa Arab dalam setiap baitnya. H. R. Hidayat Suryalaga tidak menjadikan redaksi ayat sebagai sumber, tetapi ia berusaha menuangkan interpretasinya sendiri. Sementara dalam Nadoman Nurul Hikmah melakukan penterjemahan secara longgar dan kontekstual. Kontekstualisasi ayat al-Qur'an tersebut memberikan kesan kepada para pembacanya (pelantun) nadoman bahwa Nadoman Nurul Hikmah bisa dinikmati oleh kalangan siapa saja yang sesuai dengan semangat zaman.

Kata Kunci: Vernakularitas, Nadoman, Terjemah Tafsiriyah, Pupujian

\section{Introduction}

The term vernacularity refers to the term used by Anthony H. Johns ${ }^{1}$ to denote the localization of Islamic scholarship. It also can be interpreted as an effort to see the locality process in a work of interpretation or translation of the Qur'an. Vernacularization, as quoted by Islah Gusmian, is a process of discussing Islam locally in various parts of the archipelago, as can be seen in the Arabic script (script) jawi and pegon, many loan words are originating from Arabic and literary works. ${ }^{2}$

Tafseer and translation of the Qur'an in various parts of the archipelago have experienced developments, with the discovery of various kinds of interpretation books and translations in various languages such as; Malay, Sundanese, Javanese, Batak, and other local languages. ${ }^{3}$ Tafsir, written by the scholars of the archipelago in various languages at that time, aimed to meet the needs of libraries in his day. For example, Tahrīf fì Qulūb al-Mu'minīn fī Tafsr Sentences of Yasin's Letter by Ahmad Sanusi; and the interpretation of the Holy Verse Lenyepaneun by Moh. E. Hasim, which was published in 1984, was written in Sundanese. ${ }^{4}$

According to Nurdin Zuhdi, the characteristics and peculiarities of Indonesian interpretation are books of interpretation written using the local Indonesian language, both from the regional language and the national language. ${ }^{5}$ West Java, for example, translation from the beginning became part of the vernacularization of Islamic

\footnotetext{
${ }^{1}$ Anthony H. Johns, "Qur'anic Exegesis in the Malaya World," Andrew Rippin (ed). Approuches to the History of Interpretation of the Qur'an (Oxford: Clarendon Press, 1988), 579.

${ }^{2}$ Islah Gusmian, "Bahasa Dan Aksara Dalam Penulisan Tafsir Al-Qur'an Di Indonesia Era Awal Abad 20 M,” Mutawatir: Jurnal Keilmuan Tafsir Hadis 5, no. 2 (2015): 223-47

${ }^{3}$ Islah Gusmian, "Bahasa \& Aksara Tafsir Al-Quran Di Indonesia Dari Tradisi, Hierarki Hingga Kepentingan Pembaca,” Jurnal Tsaqafah 6, no. 1 (2010): 1-25.

${ }^{4}$ Gusmian, "Bahasa Dan Aksara Dalam Penulisan Tafsir Al-Qur'an Di Indonesia Era Awal Abad 20 M," 232.

${ }^{5}$ Nurdin Zuhdi, Pasaraya Tafsir Indonesia dari Kontestasi Metodologi hingga Kontektualisasi, (Bantul: Kaukaba Dipantara, 2014), 60.
} 
teachings. Judging from the translation technique, the translators use various methods, such as translation in dangding poetry and praise or nadoman. One of them is Nadoman Nurul Hikmah. Aesthetic translation of the Qur'an which is presented by carrying Sundanese poetry in the form of praise.

Hidayat Suryalaga's Nadoman Nurul Hikmah has the spirit of grounding the Qur'an with the value of Sundanese Tatar local wisdom. Nadoman Nurul Hikmah is part of the wealth of the archipelago's translation treasures with a poetic translation style. Therefore, this study is essential and exciting to open further studies and research related to how Nusantara Ulama adapt and adopt Qur'anic values through local poetry so that the Qur'an comes alive in the community.

Studies on the interpretation of the archipelago have been carried out by many academics, observers, and reviewers in the commentary study community. This includes the study of the translation of the Qur'ān in Sundanese. One of them is the writings of R. Hidayat Suryalaga himself who wrote about "Nur Hidayah, Saritilawah Sundanese Basa Al-Qur'an Winangun Pupuh 30 Juz, Book A", 6 In addition, Benjamin G. Zimmer in his writings describes the complexity of attraction between Javanese languages and Sundanese vis-a-vis the Koran, ideology, and liberation from domination. ${ }^{7}$ Meanwhile, there are several writings by Jajang A Rohmana which explain the theme of the poetic translation of the Qur'ān in Sundanese, including "Poetic Translation of the Qur'ān in West Java Translation of the Qur'ann in the Form of Sundanese Poetry Known as Guguritan", Poetic Translation of the Qur'an: Dangding and Praise of the Qur'ān in West Java, "Metrical Verse as a Rule of Qur'anic Translation: Some Reflections on R.A.A. Wiranatakoesoema's Soerat AlBaqarah (1888-1965),"10 "Sastra Islam Nusantara: Puisi Guguritan Sunda dalam Tradisi Keilmuan Islam di Jawa Barat,"11 and "Sundanese Translations of the Qu'ān in West Java: Characteristics and the Limits of Translation,"12

\footnotetext{
${ }^{6}$ HR. Hidayat Suryalaga, Nur Hidayah, Saritilawah Basa Sunda Al-Qur'an Winangun Pupuh 30 Juz, Buku A, (Bandung: Yayasan Nur Hidayah, 2000).

${ }^{7}$ Benjamin G Zimmer, “Al-'Arablryah and Basa Sunda: Ideologies of Translation and Interpretation among the Muslims of West Java," Studi Islamika 7, no. 3 (2000): 31-65.

8 Jajang A. Rohmana, "Poetic Translation of the Qur'an in West Java Translation of the Qur'an in the Form of Sundanese Poetry Known as Guguritan," Suhuf 8, no. 2 (2015): 175-202, https://doi.org/10.22548/shf.v8i2.

9 Jajang A. Rohmana, Terjemahan Puitis Al- Quran: Dangding Dan Pupujian Al- Quran Di Jawa Barat (Jawa Barat: Layung, 2019).

10 Jajang A. Rohmana, "Metrical Verse: As a Rule of Quranic Translation: Some Reflections on R.A.A. Wiranatakoesoema's Soerat Al-Baqarah (1888-1965)," Al-Jami'ah 53, no. 2 (2015): 439-67, https://doi.org/10.14421/ajis.2015.532.439-467.

${ }^{11}$ Jajang A Rohmana, "Sastra Islam Nusantara : Puisi Guguritan Sunda Dalam Tradisi Sastra Islam Nusantara:", Akademika 21, no. 1 (2016): 1-18, https://www.researchgate.net/publication/ 340683983_Sastra_Islam_Nusantara_Puisi_Guguritan_Sunda_Dalam_Tradisi_Keilmuan_Islam_Di_Jaw a_Barat/link/5e992efe299bf13079a1 eafa/download.

12 Jajang A Rohmana, "Sundanese Translations of the Qur'an in West Java: Characteristics and the Limits of Translation," DINIKA : Academic Journal of Islamic Studies 2, no. 2 (2017): 165-200, https://doi.org/10.22515/dinika.v4i2.1713.
} 
Even though there have been many studies on the translation of the Qur'an in Sundanese, studies with the theme of vernacularity in Nadoman Nurul Hikmah's poetic translation of the Qur'an still need to be carried out as an effort to internalize the values of the Qur' an according to the spirit of place and time.

By using a descriptive method, this article aims to explain the form of vernacularity in the translation of Nadoman Nurul Hikmah's interpretation by HR Hidayat Suryalaga, where the researcher sees that the aspect of nadoman content or the meaning of the verse in Nadoman Nurul Hikmah is much more accurately called the translation of the Qur'àn interpretation. Rather than being called a poetic interpretation of the Qur'an because, in each of his stanzas, HR Hidayat Suryalaga does not at all refer to the translation or interpretation in Arabic and does not use the verse editor as a source. While in the form of translation, it seems loose. This translation is reflected in the contextual style of interpretation which gives the impression to the readers (singers) of Nadoman that anyone can enjoy Nadoman Nurul Hikmah by the spirit of the times. Thus, this paper is expected to contribute to introducing local interpretations of the archipelago.

\section{Biography of H. R. Hidayat Suryalaga}

Abah Surya, as he is usually called, is a Sundanese writer and humanist. He finished the People's School (SR) in 1954. Then he continued his SGA and finished in 1961. He studied at FKIP until level III and graduated at the Unpad Faculty of Letters in 1986.

His career started as a SR/SD teacher from 1958-1966, a junior high school teacher from 1966-1978. From 1978-1980 he was a lecturer at the Unpad Faculty of Letters until 1998. And in 1992 he also started teaching at Unpas until 2001.

Apart from teaching, Mr. Hidayat also wrote several books related to Sundanese culture. In addition, Abah Surya also often writes drama scripts. There are thirty-six scripts and almost all of them are staged. In fact, he has also been a script actor several times with the Kiwari theater which was founded in the 1970s.

Abah Surya is also active in various social organizations, including; Editor of Kalawarta Kudjang (1966-1978), chairman of the Sunda Atikan Foundation (19961998), chairman of Daya Sunda (1994), LBSS administrator (2000-2005), founder/advisor of the Kiwari Sunda Theater (1975-2011), chairman of the Unpas Cultural Institute (1992-2000), Unpas Cultural Expert Staff (2000-2004), advisor to the Penca Daya Sunda hermitage, Daya Students Sunda (Damas), and a member of Bandoeng Tempoe Doeloe.

\section{Nadoman Nurul Hikmah}

Nadoman Nurul Hikmah The themes of the verses of the Koran Daras 30 written by Hidayat Suryalaga is a book published by the Nur Hidayah Foundation in Bandung in 2010. This 216 page thick book contains the composition of nadoman 
based on the letter of the Koran daras juz 30 Hidayat compiled his work from chapters 1 to 30 for about 12 years (1997-2009). This work was composed by him after performing the pilgrimage in $1418 \mathrm{H} / 1997 \mathrm{AD}$, precisely after writing a work entitled, Nur Hidayah: Saritilawah Basa Sunda, Al-Qur'an 30 Juz Winangan Pupuh (1980). ${ }^{13}$

Nadoman Nurul Hikmah consists of 30 series per juz, of which are printed in the form of a pocket book. In 30 juz of the Qur'an there are about 5750 nadom poems. The average length is 300 series of praise themes. Hidayat attempted to translate the Qur'ann into the form of praise by dividing it into several theme titles, one theme consisting of one verse or several verses. each theme has 5-10 stanzas of praise. The quartet pattern he chose refers to the provisions of 4 lines in each stanza and 8 syllables (engang).

Hidayat's work cannot be separated from the tradition of praise that he hears every day in mosques. In his speech, he admitted that his work was motivated more by his concern for the limitations of the lyrics of the praises sung in mosques which seemed monotonous. In addition, he witnessed many preachers who simply khatam the Qur'an and do not like to read translations or interpretations, so that understanding of the Qur'an is not deep. Therefore, Hidayat's efforts to compose praises and verses from the Qur'an are more or less related to these concerns. In addition, according to Hidayat Nadoman Nurul Hikmah, it contains the internalization (ngantebkeun) of the verses of the Qur'an so that Muslims from small children to adults know how to live in the world. Even compared to Saritilawah Nur Hidayah which was compiled in the form of pupuh, Nadoman Nurul Hikmah did not require special skills in developing it, so that his praises could be chanted freely. He also uses the more popular Sundanese and contextual material. For example, he incorporates illustrations into everyday life, to attract the interest of the younger generation as the successors of the Ummah. ${ }^{14}$

Judging from his limitations in Arabic, Hidayat uses an Indonesian translation of the Qur'an as his main source. He did not refer directly to the Arabic Qur'an. For example, he used the Qur'an and its translation published by the Ministry of Religion of the Republic of Indonesia in the 1990 edition and the printed edition of the Kingdom of Saudi Arabia in 1415 H. In addition, he used the book asbāb al-nuzūl by KH. Qamarudin Salih, Collection of Hadith Qudsi by M. Ali Usman et al., and Saritilawah Nur Hidayah by himself. Unfortunately, none of the works of interpretation of the Qur'an, both in Arabic and in Indonesian, are used as references. ${ }^{15}$

\section{The form of vernacularity of the poetic translation of the Qur'an by Nadoman Nurul Hikmah}

Nadoman Nurul Hikmah by H. R. Hidayat Suryalaga with the terms of Sundanese cultural symbols. Not only translating from the source language to the

\footnotetext{
${ }^{13}$ R. Hidayat Suryalaga, Nadoman Nurul Hikmah, Tema-tema Ayat Al-Qur'an Daras 30 (Bandung: Yayasan Nur Hidayah, 3003).

14 Suryalaga, 193.

${ }^{15}$ Rohmana, Terjemahan Puitis Al- Quran: Dangding Dan Pupujian Al- Quran Di Jawa Barat, 147.
} 
target language (Sundanese), Nadoman Nurul Hikmah is rich in cultural values and local wisdom. This adoption and adaptation process shows that diversity does not only exist in language and script, but also aims at the interests of the commentators towards Muslim citizens through an interpretive language that is suitable for the context of the local community.

In this study, the author focuses on Nadoman Nurul Hikmah daras 30 or juz 30. Nadoman Nurul Hikmah is a unique and unique translation of the Koran. The location of its peculiarity and uniqueness lies in the form of praise which is one of Sundanese poetry. This praise is what distinguishes Nadoman Nurul Hikmah's translation of the Qur'an from translations from other regions and shows Sundanese characteristics. There are 3 themes presented, namely, monotheism, stories, and muamalah. This categorization is important to reveal the vernacularity of every praise that comes from the verses of the Qur'ān, especially the chapters of Juz 30.

The theme of monotheism: Qs. Al-Ikhlas/112: 1-4

No. 307. Gusti Alloh Anu Maha Esa (: 112/1)

(God Almighty)

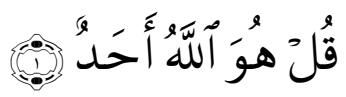

Original Text

Bismillah awitanana,(8a)

pupujian salajengna (8a)

al-Ikhlas dimutola'ah, (8a)

kalebet surat Makiyah. (8a)

Nadoman surat Al-Ikhlas, (8a)

kaimanan ulah waswas, (8a)

yên Alloh Nu Maha Esa, (8a)

Alloh Nu Maha Kawasa. (8a)

Mangga urang sasarengan, (8a)

kedal ucap pangankenan, (8a)

mung Alloh Nu Maha Esa, (8a)

sembaheun sugri makhlukna. (8a)

Teu aya deui ilahi, (8i)

salintang Illahi Robbi, (8i)

gusti Alloh Maha Suci, (8i)

sinembah ingkang Sawiji. (8i)

Kanggo mu'min nu sajati, (8i)

rukun iman nu kahiji, (8i)

sahadat tawisna Islam, (8a)
Translation

Bismillah let's start

next compliment

Al-Ikhlas studied

including Makiyah letters

Nadoman Surah Al-Ikhlas

Faith don't worry

that God Almighty

Almighty God

Let's be together

while confessing

only Allah Almighty

The worship of all creatures

No more God

other than Allah Robbi

Lord God is holy

The One Devotion

For true mu'min

the first pillar of faith

Sahadat is Islamic 


\section{kedah yakin kedah paham. $(8 a)^{16} \quad$ Must be sure, must understand}

The translation of the praises of the Qur'an basically has the same rules as other types of praise that contain religious teachings or advice. The content of the translation of the holy verses of the Qur'ān is the difference. The author when compiling the translation of the praises of the Qur'ān, in addition to paying attention to the source language (Arabic), must also consider the rules of praise that form the pattern of his composition. The rules of praise must be related to its status as song lyrics. The type of song may vary according to the number of lines and syllables.

In the translation of the praise of QS. Al-Ikhlas, Hidayat Suryalaga refers to the rules of praise poetry using the provisions of 4 lines in each stanza (kwatren), 8 syllables per line, and the last vowel a-a-a-a in the first verse and only one stanza using the final vowel $\mathrm{i}-\mathrm{i}-\mathrm{a}-\mathrm{a}$.

Judging from the content of the verse, the translation of Hidayat Suryalaga's praise QS. Al-Ikhlas above, the author sees that these verses tend not to be bound by the source language editor. He is no longer a translation of the Qur'ān, but of course it leads to a tafsiriyah translation, not a literal one. The choice of interpretive translation is not only for the convenience of translators and writers, but also from the perspective of the internal structure of the language, interpretive translation is a necessity. The factor of the rules of poetry is one of the most basic causes forcing translators to use interpretive translations.

Therefore, the most realistic choice, the translator must use a tafsiriyah translation by means of which the meaning is captured first, then choose the words that are in accordance with their meaning, while adjusting to the complex rules of the poetry of praise. Here it can be understood that generally poetic translations of this kind end up making many changes, shifts, and adjustments, the results of which are different from the source language. In fact, in the end it tends to lead to the form of interpretation.

Notice how Hidayat uses many stanzas of praise to interpret one short verse from the QS. The Al-Ikhlas. For example, in the first verse, the author enters information on the type of QS. Al-Ikhlas is included in the Makiyah letter. Furthermore, the essence of the first verse of QS. Al-Ikhlas is about the oneness of God and then interpreted by including the first pillars of faith that must be sure and understand for true believers. ${ }^{17}$

308. Sadaya Makhluk Gumantung Kana Iradah Alloh Swt. (:112/2)

(All creatures depend on Allah's Iradah).

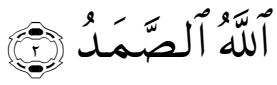

Original Text

Translation

\footnotetext{
${ }^{16}$ Suryalaga, Nadoman, 201-202.

17 Suryalaga, 201.
} 
Nadoman nu salajengna, (8a) surat al-Ikhlas sumberna, (8a) dupi nu jadi ayatna, (8a) nyaêta ayat kadua. (8a)

Mung Alloh Nu Maha Esa, (8a) nu nyiptakeun jagat raya.(8a) sadaya sugri makhlukna, (8a) mung gumantung ka Mantenna. (8a)

Mung ka Alloh urang muji, (8i) wiridan asma Illahi, (8i) ka Alloh urang neneda, (8a) mugi dijaga diraksa. (8a)

Ka Alloh nu Maha Agung, (8u) urang nyuhunkeun papayung, ( $8 u)$ sumalindung mung ka Gusti, (8i) ka Alloh Illhi Robbi. $(8 i)^{18}$
The Next Nadoman

Surah Al-Ikhlas is the source

as for the verse

that is the second verse

Only Allah Almighty

who created the universe

all the creatures

Just hang on to Him

Only to Allah do we praise

Wirid Asma Allah

to Allah we pray

May it be protected

To Allah the Greatest we ask for protection take refuge only in Allah To Allah Illahi Robbi

In the second verse, the author uses a more varied pattern, not only the final vowel a-a-a-a, but also uses the patterns of $\mathrm{i}-\mathrm{i}-\mathrm{a}-\mathrm{a}$, and $\mathrm{u}-\mathrm{u}-\mathrm{i}-\mathrm{i}$. This shows that the author is not too attached to very strict rules of praise and does not pursue the final vowel to be the same rhythm (murwakanti).

In this verse, Abah Surya is still discussing the oneness of God. Allah is the creator of the universe. Therefore, all of his creatures must depend on the Creator, ask for protection, and take refuge only in Allah, the Rabbi. That's how Abah Surya translates. In both the first and second verse, Abah Surya gives explanation (mensyarah) the lexical word with other stanzas as an explanation. For example in Allah alșamad which means Allah is the dependent. He explained other than Allah a place to lean on, that Allah is also a place to ask for help. This illustrates that Abah Surya is not only fixated on lexical meanings, but also gives other meanings to strengthen the nature of God Almighty.

309. Alloh Anu Maha Esa (:112/3-4)

(God Almighty)

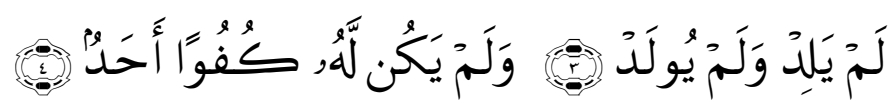

Original Text

Surat Al-Ikhlas lajengkeun, (8eu) ayat katilu dangukeun,(8eu)
Translation

Continue Surah Al-Ikhlas

The third verse listen

\footnotetext{
${ }^{18}$ Suryalaga, 202.
} 
nema ayat kaopatna,(8a)

nyanggakeun nadomanana. (8a)

Mangga urang kedal lisan, (8a) kedal ucap pangangkenan, (8a) Alloh teu kagungan rama, (8a) sareng teu kagungan putra.(8a)

Alloh Anu Maha Suci, (8i) henteu aya nu nyasami, (8i) henteu aya nu nandingan, (8a) Alloh agung tan wangenan. (8a)

Aya riwayat ti Dohhaq, (8a) ku ulama geus kapendak, (8a) yên nu kapir ngajurungan, (8a) Amin bin Tufail ngaran. (8a)

Ngahaja nepangan Nabi, (8i) ngabibita rupi-rupi, (8i) bilih palay kabeungharan, (8a) atawa kakawasaan. (8a)

Kangjeng Nabi ngawaleran, (8a) anjeunna ukur utusan, (8a) ngajak jalma sangkan iman, (8a) ka Alloh sujud miiman. (8a)

Henteu palay harta banda, (8a) henteu palay kumawasa, (8a) manahna ihlas sumerah,(8a) ka Gusti alloh sumembah. (8a)

Torojol nu kapir deui, (8i) ngahaja nepangan Nabi, (8i) cik ari Alloh Ta'ala, (8a) tina emas dijieunna? (8a)

Nya lumungsur ieu ayat, (8a) kitu numutkeun riwayat, (8a) ieu ayat asal-usul, (8u) disebat asbāb al-nuz̄̄l.(8u)

Aya hadis netelakeun,(8eu) yên upami dibandingkeun, (8eu) Surat al-Ikhlas ajenna, (8a) sepertilu Qur'an mulya. (8a) continue the fourth verse please the nadom

Let's say confess God doesn't have a father and doesn't have children

Holy God nothing compares to nothing compares God is great and unchanging

There is a history from Dohaq by scholars have found that the disbelievers command Amin bin Tufail his name is

Accidentally met the Prophet, incite all kinds if you want wealth or power

The Prophet replied he's just a messenger invite people to faith to Allah prostrate believe

Don't want possessions don't want power his heart sincerely surrenders To Allah worship

Again the disbelievers come accidentally met the Prophet is Allah ta'ala made of gold?

Drop this verse so based on history, ieu verse of origin called asbāb al-nuzūl

there is a hadith explaining that when compared Surah al-Ikhlas itself One third of the noble Qur'ān 
Dina lebet Hadis Qudsi, (8i)

Ibnu Khuzaimah nampi, (8i)

sumberna awit ti Anas, (8a)

kateranganana jelas. (8a)

Alloh kalintang benduna, (8a)

ka nu bohong itikadna, (8a)

pajar Alloh 'mo tiasa, (8a)

ngahirupkeun deui jalma. (8a)

Jeung ka jalma nu teu sopan, (8a)

pajar Alloh teh putraan,(8a)

nya dua hal ieu pisan, (8a)

lungsur la'nat ti Pangeran. (8a)

Mun keresa napakuran, (8a)

Al-Ikhlas teh dilenyepan, (8a)

eusina katauhidan, (8a)

sumber takwa kaimanan. $(8 a)^{19}$
In the Qudsi Hadith

Ibn Khuzaimah accepted

source from Anas

The explanation is clear

God is so angry

to people who lie in their intentions

Assuming God can't

Bringing humanity back to life

And impolite people

think that God has children

these two things

cursed from Allah

If you want to reflect

Al-Ikhlas to be contemplated

in monotheism

source of piety of faith

Abah Surya in the third and fourth verses includes a number of elements of information sourced from asbāb al-nuzūl and hadith so that it is rich in important information in the translation. Using more varied patterns ranging from e-e-a-a, a-a-aa, to i-i-a-a. In this verse, Abah Surya's interpretation is very clear by quoting a hadith narrated by Dohhaq in the verse "yen kapir ngajurungan, Amin bin Tufail ngaran. Ngahaja spanking the Prophet, took a couple of rupees." In other words, Abah Surya tries to give his interpretation by using the tafsr bi al-riwāyah method in several verses of his translation of praise. The same thing can be found in the verse "Aya hadith netelakeun, yen upami compared to keun. Surah Al-Ikhlas Ajenna, like the Qur'ān Mulya".

From the translation of the praise of QS. Al-Ikhlas above, it can be seen that these verses tend not to be bound by the source language editor. He is no longer a translation of the Qur'ān, but tends to go beyond and enter the realm of poetic "tafsir" of the Qur'ān. Notice how Abah Surya uses many verses of praise to interpret a short verse from the QS. The Al-Ikhlas. The indicator of interpretation is also seen in the use of historical information from Dohhaq and Anas in the poetry of verses three and four above. This is strong evidence that Hidayat's praise is no longer a poetic translation, but tends to shift the interpretation of the verse into a form of praise or interpretation of translation.

The above characteristics appear in the use of several stanzas to interpret a short verse. Abah Surya seems to give a theological interpretation of the four verses of the QS. Al-Ikhlas. The stanzas show that he did not translate the source language editorial,

\footnotetext{
${ }^{19}$ Suryalaga, 202-203.
} 
but gave an explanation of one verse based on his understanding. In other words, Hidayat Suryalaga seems to tend to be more lax in translating the source language.

Story Theme: Qs. Al-Lahab/111: 1-5

303. Leungeun Abi Lahab Dila'nat Anu Banget Pisan (111/1)

(May the hands of Abū Lahab be ruined, and ruined is he)

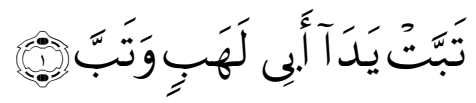

Original Text

Ngawitan ngaos bismillah, (8a)

Surat Al-Lahab sarsilah,(8a)

kalebet Surat Makiyah,(8a)

Ayena dimutol'ah.(8a)

Nadoman surat Al-Lahab,(8a)

Seuneu nu nguntab-ngauntab,(8a)

ayat anu kahiji,(8i)

regepkeun masing taliti.(8i)

Leungeun Abi Lahab hina,(8a)

dila'nat ku Nu Kawasa,(8a)

sabab nya leungeuna pisan,(8a)

anu nyieun karusakan.(8a)

Abu Lahab paman Nabi, (8i)

tapi ka Nabi teh dengki,(8i)

Islam arek diancurkeun,(8eu)

reka perdaya teu eureun(8eu)

Nu mawi Kersa Illahi,(8i)

kenging pangla'nat Gusti, (8i)

zun katuhu jeung kenca, (8a)

leungeun Abu Lahab nista. $(8 a)^{20}$
Translation

At first read Bismillah, Surah Al-Lahab according to history including Makiyah letters

Now reviewed

Nadoman Surah Al-Lahab, blazing fire,

first verse,

pay close attention

Abi Lahab's hands are despicable, cursed by the Almighty, because his hands do damage.

Abu Lahab uncle of the Prophet, but to the envious Prophet, Islam is about to be destroyed endless deception.

By God's will, get the curse of God, right and left hand, Abu Lahab's hands were despicable

In the first verse, Abah Surya uses the quaternary pattern a-a-a-a, a-a-i-i, i-i-eu$\mathrm{eu}$, and i-i-a-a. Before entering the first verse, he explained that the QS. Al-Lahab includes Makiyah verses. Abah Surya, in the first verse, gives the meaning of al-Lahab with seuneu anu nguntab-nguntab (flaming fire). He also informed that Abu Lahab was the uncle of the Prophet. As mentioned above, Abah Surya is not too attached to a rigid translation of the Koran. He prefers to include the information contained in asbāb

\footnotetext{
${ }^{20}$ Suryalaga, 198.
} 
al-nuzūl in his nadom. The point of the first verse is found in the last stanza which explains that Abu Lahab's hands are despicable and contemptible.

\section{Henteu Mangpaat Rajakayana Abi Lahab (:111/2)}

(His wealth will not avail him or that which he gained)

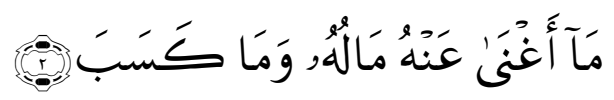

Original Text

Surat Al-Lahab lajengna, (8a) dupi nu jadi ayatna, (8a) nyaeta ayat kadua, (8a) nyanggakeun ieu nadomna. (8a)

Abi Lahab jalma kaya, (8a) harta kacida lobanna, (8a) saudagar dagang kawentar, (8a) kebonna manghektar-hektar. (8a)

Tapi sakabeh bandana, (8a) hartana bandana teu guna, (8a) rajakayana mubadir, (8i) ukur papaes di lahir. (8i)

Digunakeun teu mangpaat, (8a) malah dipake hianat, (8a) nu matak jaga ahirna, (8a) Abi Lahab ka naraka. (8a) ${ }^{21}$
Translation

\begin{abstract}
Abi Lahab's next letter, as for the verse, namely the second verse, please this is nadom.
\end{abstract}

Abi Lahab the rich man, very rich, famous merchant The garden is acres

But all his wealth, worthless money, wasted wealth, Just a birth decoration.

Use is useless, even used treacherously, eat it later

Abi Lahab is going to hell

The pattern in the second verse uses two patterns, a-a-a-a, and a-a-i-i. It has become a characteristic (landmark) of Nadoman Nurul Hikmah, before entering the main explanation of each verse, it is preceded by an opening stanza so that the reader or singer of Nadoman can be an effort to focus more first.

The phrase mā aghnā 'anhu māluhu wa mā kasab only implies that Abu Lahab is a rich person. However, in Abah Surya's nadom, he illustrates Abu Lahab's wealth by explaining that Abu Lahab was a well-known merchant and owned acres of gardens. In these verses, Abah Surya does not discuss Abu Lahab at all from the side of his family or descendants. This is understandable, Abah Surya only refers to the book asbāb alnuzūl translated by Qomaruddin Salih which does not provide an explanation of the QS. Al-Lahab from the side of his family or descendants. ${ }^{22}$ This shows that Abah Surya was a creative translator, to illustrate an Abu Lahab who was very rich during his

\footnotetext{
${ }^{21}$ Suryalaga, 199.

${ }^{22}$ Lihat al-Tabari yang mengartikan frasa wa mā kasab adalah anak-anaknya. Al-Tabari, Jāmi' alBayān fi Ta'wīl Ay al-Qur'ān. Terj Amir Hamzah. Jilid 26. Cet. I (Jakarta: Pustaka Azzam, 2009), 1006.
} 
lifetime. Until he entered the essence of the verse that all his possessions were useless and could not help him from the torment of hell.

305. Abi Lahab Jeung Bojona Bakal Asup Naraka (:111/3).

(Abi Lahab will [enter to] burn in a Fire of [blazing] flame).

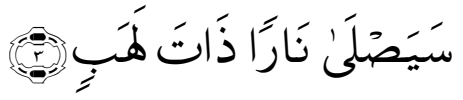

Original Text

Al-Lahab ayat katilu, (8u)

eusina moal kaliru, (8u)

sumberna ieu nadoman, (8a)

Mangga urang bandungan. (8a)

Abi Lahab jeung bojona, (8a)

jalma kapir geus tetala, (8a)

mindeng pisan nganiaya, (8a)

Jalma muslim dipergasa. (8a)

Abi Lahab jeung bojona, (8a)

jalma doraka kacida, (8a)

bakal asup ka naraka, (8a)

sarta langgeng disiksana. (8a)

Sabab keur waktu hidupna,(8a)

gawena rek perdaya, (8a)

Islam arek dipareman, (8a)

Nabi arek ditelasan. (8a)

Padahal Kangjeng Nabi teh, (8e)

kalebet alona keneh, (8e)

Abi Lahab jeung bojona, (8a)

nyarieun reka perdaya (8a)

Riwayat ti Ibnu Jarir, (8i)

nya kitu ti Ibnu Mundzir, (8i)

sumberna ti Ikrimah, (8a)

ayana ieu risalah (8a)

Ari bojo Abi Lahab, (8a)

kacida pisan biadab, (8a)

nyebarkeun cucuk di jalan, (8a)

nu Ku Nabi kalangkungan. (8a)

Atuh tangtos Kangjeng Nabi, (8i)

angkat kedah ati-ati, (8i)

margi cucuk rungseb pisan, (8a)
Translation

Al-lahab third verse, the content will not be wrong, the source is nadoman, let's take a look.

Abi Lahab and his wife, clear disbeliever, often abuse, Muslims are oppressed.

Abi Lahab and his wife, very sinner, going to hell, and eternally tormented.

For when his life their work is deceiving, Islam wants to be extinguished The Prophet wanted to be killed.

Even though Kangjeng the Prophet, including his uncle's son,

Abi Lahab and his wife, trick.

History from Ibn Jarir, as well as from Ibn Mundhir, source from Ikrimah, there is this treatise.

While the wife of Abi Lahab, very cruel, spread thorns on the road, through which the Prophet passed.

Of course Kangjeng Nabi, walk carefully, because the thorns are so sharp, 
mun raheut sok nyanyautan. $(8 a)^{23} \quad$ If the wound hurts.

Verse by stanza of the third verse, Abah Surya wants to present the situation of Abu Lahab and his wife with a causal pattern. Abu Lahab and his wife will be punished by hell because during their lifetime they made a trick with the intention of dimming the teachings of Islam and killing the Prophet Muhammad.

$\mathrm{He}$ cites narrations from Ibn Jarir and Ibn Mundzir from Ikrimah. It was explained that Abu Lahab's wife was a very cruel person. His wife spread thorns on the streets that the Prophet Muhammad used to walk. Ibn Mundzir's narration, which is sourced from Ikrimah, refers to the book Lubbāb al-Nuqūl fì Asbāb al-Nuzūl by Jalāl al-Dīn al-Suyūtị which was translated into Indonesian by Qomaruddin Shaleh assisted by A. A. Dahlan and M. D. Dahlan. ${ }^{24}$ In this third verse we can see more varied patterns such as u-u-a-a, e-e-a-a, and i-i-a-a. The a-a-a-a pattern is still used in some stanzas.

\section{Bojona Abi Lahab Tukang Nyebarkeun Pitnah (:111/4-5)}

(And his wife [as well] - the carrier of firewood).

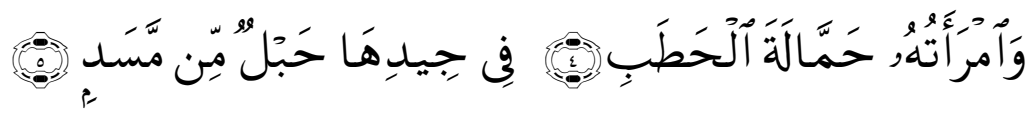

Original Text

Al-Lahab nu salajengna, (8a)
nyanggakeun ieu nadomna, (8a)
ayat anu kaopatna, (8a)
teras ayat nu kalima. (8a)

Tukang mitenah geus puguh, ( $8 u)$ ibarat ngagandong suluh, ( $8 u)$ suluh garing na tonggongna, (8a) ngiderna kamana-mana. (8a)

Nyebarkeun fitnah jeung rumor, (8o) ngomongna pinuh kokotor, (8o) masarakat jadi ribut, ( $8 u)$ parasea durder gelut. ( $8 u$ )

Nu matak engke ahirna, (8a) jalma tukang fitnah tea, (8a) diduruk tututng awakna, (8a) sarta langgeng di naraka. (8a)

Beuheungna ge ditalian, (8a)

\section{Translation}

The next Al-Lahab, please this is nadoman, fourth verse, then the fifth verse.

The slanderer is clear like carrying wood dry wood on his shoulders around everywhere

Spreading slander and rumors talk full of dirt, people are noisy, fight fight.

Eat it in the end slanderer, his body burned, and eternal in hell.

His neck is tied,

\footnotetext{
${ }^{23}$ Suryalaga, Nadoman, 199.

${ }^{24}$ Lihat Qomaruddin Shaleh et al., Asbabun Nuzul: Latar Belakang Historis Turunnya Ayat-Ayat alQur'an (Bandung: CV. Dipenogoro, 1999), 624.
} 


\begin{tabular}{|c|c|}
\hline $\begin{array}{l}\text { ku injuk nu pageuh pisan, (8a) } \\
\text { disesered ka naraka, (8a) } \\
\text { dikulub keur salilana. (8a) }\end{array}$ & $\begin{array}{l}\text { very hard, } \\
\text { dragged to hell, } \\
\text { simmered forever. }\end{array}$ \\
\hline $\begin{array}{l}\text { Tah kitu geuning baraya, (8a) } \\
\text { kalakuan anu nista, (8a) } \\
\text { Abi Lahab jeung bojona, (8a) } \\
\text { kitu geuning balukarna. (8a) }\end{array}$ & $\begin{array}{l}\text { That's it brother, } \\
\text { despicable behavior, } \\
\text { Abi Lahab and his wife, } \\
\text { That's the result. }\end{array}$ \\
\hline $\begin{array}{l}\text { Ieu jadi pieunteungeun, (8eu) } \\
\text { lain pikeun picontoeun, (8eu) } \\
\text { kalakuan abi Lahab, (8a) } \\
\text { tanda jalma nu biadab. (8a) }\end{array}$ & $\begin{array}{l}\text { This is a mirror, } \\
\text { not for example, } \\
\text { Abi Lahab's behavior } \\
\text { Sign of a savage. }\end{array}$ \\
\hline $\begin{array}{l}\text { Urang ulah mirucaan, (8a) } \\
\text { nyebarkeun beja pitnahan, (8a) } \\
\text { tong resep nyebarkeun rumor, (8o) } \\
\text { ngomong bohong eta kotor. (8o) }\end{array}$ & $\begin{array}{l}\text { We don't start } \\
\text { spreading slanderous news, } \\
\text { don't like to spread rumors } \\
\text { lying is dirty. }\end{array}$ \\
\hline $\begin{array}{l}\text { Lain pagawean halal, (8a) } \\
\text { wiwirang batur diobral, (8a) } \\
\text { engke bakal kaalaman, (8a) } \\
\text { nembrak wiwirang sorangan. (8a) }\end{array}$ & $\begin{array}{l}\text { Not a lawful act } \\
\text { other people's disgrace on sale, } \\
\text { will experience later, } \\
\text { open disgrace. }\end{array}$ \\
\hline $\begin{array}{l}\text { Rengse surat Abi Lahab, (8a) } \\
\text { mugia jadi musabab, (8a) } \\
\text { pikeun ka urang ngelingan, (8a) } \\
\text { yen hirup ulah kapiran. }(8 a)^{25}\end{array}$ & $\begin{array}{l}\text { Completed Abi Lahab's letter, } \\
\text { may be the reason, } \\
\text { we realize, } \\
\text { that life is not cheating }\end{array}$ \\
\hline
\end{tabular}

In the fourth and fifth verses, it is not revealed who the real name of Abu Lahab's wife is. However, Abah Surya in his speech stated the actions of Abu Lahab's wife. It is stated that Abu Lahab's wife labeled as hammālat al-hațab is a slanderer, rumor, and provocative that is analogous to someone carrying firewood. Even in his nadom, Abah Surya makes an analogy of his firewood with dry firewood.

This was done by Abu Lahab's wife solely to dissuade people from the religion of Allah SWT, as well as to spread enmity among the people. As for the phrase fi jīdiha hablun min masad is a symbol, by Abah Surya it is interpreted lexically beuheungna ge ditalian, ku injuk nu pageuh pisan (the neck is tied, tied by a solid fiber). ${ }^{26}$ As a consequence of his wife's actions, according to Abah Surya, Abu Lahab's wife was burned to the ground, her neck was tied by a fiber rope, dragged in the fire of hell, and simmered in hell forever.

\footnotetext{
${ }^{25}$ Suryalaga, Nadoman, 200.

${ }^{26}$ Quraish Shihab, Tafsir al-Misbah: Pesan, Kesan, dan Keserasian al-Qur'an, (Jakarta: Lentera Hati, 2007), 707.
} 
In the last verse, Abah Surya invites the readers (singers) of his nadom to reflect on the story of Abu Lahab that the actions of Abu Lahab and his wife are a sign of barbaric humans. Not following his bad attitude is like spreading slander, provocation, blocking people from the path of Allah. He hopes QS. Al-Lahab is the reason that humans are aware and live not cheating.

Mu'amalah theme: Qs. Al-Ma'un/107: 1-7

294. Anu Kumaha Jelema Anu Ngagem Agama Bohong (:107/1-3)

(People Who Use Religion of Lies)

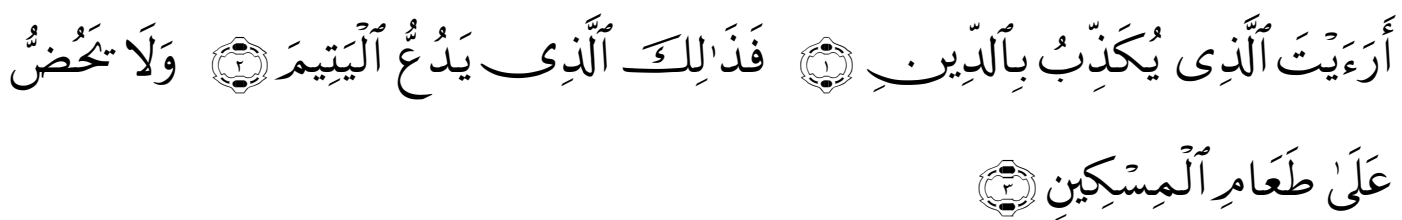

Original Text

Awitan ngaos bismillah, (8a)

al-Ma'un nu dibaladah (8a)

kalebet Surat Makiyah (8a)

ayena dimutola'ah(8a)

Dupi al-Ma'un hartosna (8a)

barang $n u$ ageung gunana (8a)

dianggo anu maslahat (8a)

dianggo keur mayar zakat(8a)

Ieu nadoman sumberna (8a)

surat al-Ma'un awitna (8a)

ayat hiji, dua, tilu ( $8 u$ )

mangga bandungan sing husu ( $8 u$ )

Eusina ieu nadoman, (8a)

maparinan katerangan, (8a)

sangkan urang jadi terang, (8a)

sadayana jadi gamblang. (8a)

Ari jelema cilaka, (8a)

eta teh aya tandana, (8a)

agama ukur cangkangna, (8a)

da henteu reujeung buktina. (8a)

Pajar geus ngagem agama, (8a)

tapi taya kanyaahna, (8a)

ka nu miskin nu malarat, (8a)

tara sidqoh mayar zakat. (8a)
Translation

Start reading Bismillah the learned al-Ma'un, including Makiyah letters, now reviewed.

As for al-Ma'un which means, useful goods, beneficial use, used to pay zakat.

This is the source, Surah al-Ma'un begins, verses one, two, three, please pay close attention.

This content is nadoman give explanation so that we can be bright everything is so clear

wretched human it has a sign religion is just a package There is no proof

He said he was practicing religion

but no love to the poor don't pay zakat 
Lamun aya nu musapir, (8i) disentak bari diusir, (8i) nu kitu teh jalma palsu, (8u) agamana ngaku-ngaku. (8u)

Allah kalintang benduna, (8a) ka nu ngaku beragama, (8a) tapi ieu bari jeung prakna, (8a) agama ukur cangkangna. (8a)
If there is a traveler rebuked while being expelled so fake pretend religion

God is so angry to those who profess to be religious but while practicing religion is just a wrap

295. Ari Sholat Kudu Husu (:107/4-5)

(If you pray, you have to be solemn)

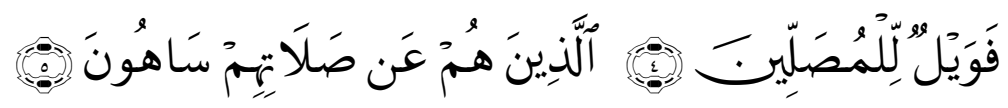

Original Text

Surat al-Ma'un lajengna, (8a)

Ayat anu kaopatna, (8a)

Nema ayat nu kalima, (8a)

Nyanggakeun nadomanana. (8a)

Numutkeun asbab al-nuzul, (8u)

Lungsur ayat usal-usul, (8u)

Riwayat ti Ibn Munzdir, (8i)

Ibn Abbas nu milahir. (8i)

Waktos jaman Kanjeng Nabi,(8i)

Aya munafik lalaki, (8i)

Osok ngahajakeun sholat, (8a)

Da loba jalma ngaliwat. (8a)

Solatna dilila-lila, (8a)

Siga nu husu kacida,(8a)

Padahal hayang kapuji, (8i)

Da loba anu ningali. (8i)

Tapi lamun euweuh jalma, (8a)

sok tara jadi solatna, (8a)

munafik kitu adatna, (8a)

sholat dibarengan riya. (8a)

Kalebet jalma cilaka, (8a)

\section{Translation}

Surah al-Ma'un next

the fourth verse

continue the fifth verse

welcome nadomnya

According to asbāb al-nuzūl

down the verse of origin

narration from Ibn Mundzir

Ibn Abbas who issued

The time of Kangjeng Nabi

there is a hypocrite man

love to pray

Because many people pass by

The prayer is delayed

like solemnly

even though I want to be praised

because many are watching

but if not people

never be the prayer

such a hypocrite behavior

prayer accompanied by riya

including wretched people 
Lamun teu husu solatna, (8a)

Rurusuhan gagancangan, (8a)

Henteu tartib babacaan. (8a)

Ari sholat anu husu, (8u)

Aya cirina geus tangtu, (8u)

$\mathrm{Nu}$ kahiji rasa ajrih, (8i)

Isin ku Allah nu asih. (8i)

Rasa sieun dipiara, (8a)

Sieun ku Alloh Ta'ala,

Sieun teu leres sholatna, (8a)

Teu panceg dina hukumna. (8a)

Kadua masing rumasa, (8a)

Nampi kadeudeuh Mantenna,(8a)

Dugi ka beueus socana, (8a)

Nyalangkrung cai socana. (8a)

Nu katilu sabar pisan, (8a)

Sholat henteu rurusuhan, (8a)

Yakin ngedeuheus Pangeran, (8a)

Malah ditambih wiridan. (8a)

Nu kaopat ngiring da'wah, (8a)

Nyebarkeun ayat risalah, (8a)

Ngagungkeun asma Illahi, (8i)

Syiar Islam nu pinuji. (8i) if you are not devoted to prayer

hurry hurry

Not orderly reading

A solemn prayer

there are characteristics of course

the first is fear

Shame on the merciful God

Fear is nurtured

afraid of Allah Ta'ala

afraid that the prayer is not correct

Inconsistent in the law

Both must feel

receive his love

until her eyes glaze over

Flowing tears

The third is very patient

prayer is not in a hurry

believe in praying to God

Even added wiridan

The fourth joins da'wah

spread the verse of the treatise

glorify God's name

The commendable symbol of Islam.

296. Tutulung teh Kedah Bari Ikhlas (:107/6-7)

(If you help, you must be sincere)

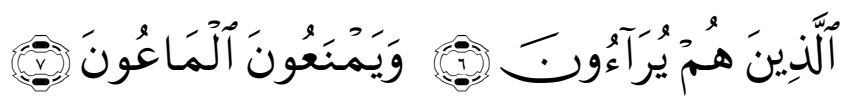

Original Text

Dangukeun masing saregep, (8e) ayatna anu kagenep, (8e) nema anu katujuhna, (8a) Surat al-Ma'un sumberna. (8a)

Komo deui mun solatna, (8a)

Ditambahan rasa riya, (8a)

Hayang kanyahoan batur, ( $8 u)$

Hayang dipuji ku batur. (8u)

\section{Translation}

Listen carefully, the sixth verse, continue the seventh verse, Surah al-Ma'un the source.

Especially when it comes to prayer added joy, want others to know Want to be praised by others.

Prayer is hablum min Allah 
Antawis mahluk jeung Alloh,(8o)

Kuduna ge iklas pisan, (8a)

Henteu aya pangarahan. (8a)

Jeung jelema anu cilaka, (8a)

Ngan ukur ngurus dirina, (8a)

Tara tutulung ka batur, $(8 \mathrm{u})$

Najan ka nu jadi dulur. (8u)

Aya parentah nu jelas, (8a)

Kuduna hablum min al-nnas, (8a)

Silih bantu sauyunan, (8a)

Sok komo jeung saiman. (8a)

Lamun urang rek nulungan, (8a)

kudu iklas mamanahan, (8a)

tutulung bari lillahi, (8i)

eta diasih ku Gusti. (8i)

Tutulung sueuer rupina, (8a)

bisa rupa-rupa cara, (8a)

nulungan maksud nu hade, (8e)

meunang pahala nu gede. (8e)

Khoirun anfa uhu, (6u)

paribasa baku, (6u)

hirup urang aya guna, (8a)

pikeun jalma anu rea. (8a)

Palasipah urang Sunda, (8a)

sami jeung muslim nu taqwa, (8a)

naha urang aya guna, (8a)

keur jelema anu rea. (8a)

Kawajiban nu utama, (8a)

diri urang aya guna, (8a)

aya mangpaat maslahat, (8a)

mangpaat keur masarakat. (8a)

tah kitu geuning baraya, (8a)

urang teh kedah waspada, (8a)

amal ibadah sing iklas, (8a)

ulah riya ulah waswas. $(8 a)^{27}$ between creatures and God,

must be sincere

no direction.

And the wretched one, only to take care of himself, never help others

Even to your brother.

There is a clear command, should be hablum min al-nnas, help each other especially with faith.

If we will help, must be sincere help while lillahi, it is loved by God.

Help many kinds, can be various ways, help good cause, get a great reward.

Khairun anfa'uhu, standard proverb, our life is useful for many people

Sundanese philosophy, the same as pious Muslims, why are we useful for many.

main obligation, we are useful, there are benefits, Benefits to society.

So brother, we must be vigilant worship must be sincere Don't worry, don't worry.

On Qs. Al-Ma'un, Abah Surya gave an interesting touch of interpretive translation. Not only citing asbāb al-nuzūl, he also seeks to harmonize local wisdom

\footnotetext{
${ }^{27}$ Suryalaga, Nadoman, 188-190.
} 
values with Qur'anic values. The most obvious stanza is found in verses 6-7. In this verse, the philosophy of the Sundanese is equated with a pious Muslim. This can be seen from the kwatren (verse) of Palasipah urang Sunda, sami jeung muslim nu taqwa, naha urang aya guna, keur jalma anu rea.

In the midst of Sundanese society, there is a sabilulungan philosophy which means penance, compassion, and care in Sundanese. While in Indonesian it means mutual cooperation, mutual help, shoulder to shoulder in one word. Dismissing selfserving and prioritizing a common goal. All play a role according to their abilities, whether in the form of material, knowledge or energy. ${ }^{28}$

Through QS. Al-Ma'un, Abah Surya emphasizes the balance between hablun min Allah and hablun min al-annās; relationship between God and man. In the context of his relationship with Allah (hablun min Allah), Abah Surya reminded people to worship sincerely, selflessly, and not to be seen by people (riya). Meanwhile, in relation to human relations (hablun min al-annas), Abah Surya invites his readers or nadom singers to help each other, especially to brothers and sisters in the faith. The same meaning is also found in other interpretations of the archipelago such as in Tafsir-Al-Azhar written by Hamka. ${ }^{29}$ Hamka in interpreting Surah Al-Ma'un also recommends that humans do worship sincerely without riya, only hoping for blessing from Allah. In addition, Hamka also encourages humans to help people in need and eliminate hatred towards fellow humans by using local words (Minang) such as using the word sejiran, fierce, encouraging, etc.

Although Abah Surya did not provide an explicit explanation of the philosophy of life of the sabilulungan, the author believes that this proverb which contains the value of local wisdom is Abah Surya's attempt - in Gusdur's term-to indigenize Islam. ${ }^{30}$

In the indigenization of Islam, it is illustrated how Islam as a normative doctrine handed down from God integrates into the culture that comes from humans without losing their respective identities, so that there is no more purification of Islam or the process of equating it with the religious practices of the Muslim community in the Middle East. ${ }^{31}$

The essence of the indigenization of Islam is to make religion and culture no longer contradict each other, but a process of vernacularization of the Qur'an into the values of local wisdom of the Sundanese people so that they are more "close and live " together in the midst of everyday life. He not only explains the meaning behind the verse, but also integrates the concepts and values of his teachings into Sundanese

\footnotetext{
${ }^{28}$ Ira Indrawardana, "Kearifan lokal adat masyarakat Sunda dalam hubungan dengan lingkungan alam”, Komunitas: International Journal of Indonesian Society and Culture 4, no. 1 (2012): 1-8. DOI: https://doi.org/10.15294/komunitas.v4i1.2390.

${ }^{29}$ HAMKA-Tafsir-Al-Azhar-Juz-30-pdf,153- 154

30 Abdurrahman Wahid, Pergulatan Negara, Agama, dan Kebudayaan, (Jakarta: Desantara, 2001), 111.

${ }^{31}$ Wahid, 111.
} 
cultural thought. There is a touch of Islamic concepts and values that require dialogue and coordination with the perspective of wisdom

However, Abah Surya's work is not without its weaknesses. From the examples of these short chapters 30, the author found a very basic weakness in Nadoman Nurul Hikmah. Among the weaknesses contained in it is the lack of references to Arabic interpretations and interpretations of commentators from Indonesia. This can not be separated from his limited ability to speak Arabic because his educational background comes from the Unpad Faculty of Letters, Regional Language Department. In his speech, Abah Surya actually refers to the 1990 translation of the Ministry of Religion of the Republic of Indonesia. Likewise in the book of asbāb al-nuzūl and the hadith narrations he refers to his translated books. ${ }^{32}$

When viewed from this background, Abah Surya is more accurately called a religious writer, compared to a translator or commentator of the Qur'ān. He himself admitted in Nadoman Nurul Hikmah's introduction that his work was not a translation, interpretation or ta'wil of the Qur'ān. He prefers that his work is called saritilawah (praise, Islamic poetry anu murwakanti, kwatren, gurindam or rhymes from nasyid sources). ${ }^{33}$ Due to his passion and love for the Qur'ān, his limitations did not prevent him from remaining productive. So that Nadoman Nurul Hikmah should be a motivation for the Qur'ān activists or academics so that the Qur'ān and traditions remain sustainable and live best in the midst of our daily lives.

\section{Conclusion}

The vernacularity of the poetic translation of the Qur'ān Nadoman Nurul Hikmah by Hidayat Suryalaga lies in its peculiarity in using the language and rules of Sundanese poetry of praise. The composition of praise is generally bound by the rules of poetry in the form of the number of lines, the number of syllables in each line, and the similarity of the final vowel sound in each line. The number of lines in Nurul Hikmah's praise uses 4 lines like Arabic poetry. While the syllables generally use eight syllables.

As for the aspect of the content (content) of the nadoman or the content of the meaning of the verse, Nadoman Nurul Hikmah is far more accurately called a translation of tafsiriyah al-Qur'an rather than being called a poetic interpretation of the Qur'ān. This is because in each of his stanzas, Abah Surya does not at all refer to the Arabic translation or interpretation and does not use the verse as the source. Abah Surya seems to be trying to come up with his own interpretation. The loose translation tends to provide a lot of additional explanations for the redaction of sentences that do not match the source language. Even some translations are filled with interpretation.

\footnotetext{
${ }^{32}$ Suryalaga, Nadoman, 213.

${ }^{33}$ Suryalaga, vi.
} 
For example, in some translations, he added additional interpretations quoted from the book asbāb al-nuzūl or hadith narrations in Indonesian.

The looseness of translation is also reflected in the contextual style of interpretation. The contextualization of the verses of the Qur'ân gives the impression to the readers (singers) of Nadoman that Nadoman Nurul Hikmah can be enjoyed by anyone who is in accordance with the spirit of the times.

\section{REFERENCES}

Al-Qaț̣ān, Mannā'. Mabāhits fì 'Uhūm al-Qur'ān. Kairo: Maktabat al- Wahbah, 2004.

Al-Tabari, Jāmi' al-Bayān fi Ta’w̄̄l Ay al-Qur'ān. Terj Amir Hamzah. Jil. 26. Cet. I. Jakarta: Pustaka Azzam, 2009.

Darmawan, Dadang. "Ortodoksi Tafsir: Respons Ulama terhadap Tafsir Tamsjijatoel Moeslimin Karya KH. Ahmad Sanusi”. Disertasi UIN Jakarta: SPS UIN Jakarta, 2009.

Gusmian, Islah. "Bahasa \& Aksara Tafsir Al-Quran Di Indonesia Dari Tradisi, Hierarki Hingga Kepentingan Pembaca." Jurnal Tsaqafah 6, no. 1 (2010): 1-25. . "Bahasa Dan Aksara Dalam Penulisan Tafsir Al-Qur'an Di Indonesia Era Awal Abad 20 M.” Mutawatir: Jurnal Keilmuan Tafsir Hadis 5, no. 2 (2015): 223-47.

Hendrayana, Dian. Puisi Sunda Seperempat Abad Terakhir dalam Penguatan Budaya Lokal sebagai Peneguh Multikulturalisme Melalui Toleransi Budaya. Konferensi Internasional Ikatan Dosen Budaya Daerah Indonesia, 2017.

Indrawardana, Ira. "Kearifan lokal adat masyarakat Sunda dalam hubungan dengan lingkungan alam", Komunitas: International Journal of Indonesian Society and Culture 4, no. 1 (2012): 1-8. DOI: https://doi.org/10.15294/komunitas. v4i1.2390.

Johns, Anthony H. "Qur'anic Exegesis in the Malaya World" dalam Andrew Rippin (ed). Approuches to the History of Interpretation of the Qur'an. Oxford: Clarendon Press, 1988.

Kurnia, Ganjar. Deskripsi Kesenian Jawa Barat. Bandung: BIP, 2003.

Mursalim, "Vernakularisasi al-Qur'an di Indonesia: Studi Kajian Tafsir al-Qur'an," Jurnal Komunikasi 16 no. 1 (2014).

Ramlan, M. Morfologi Suatu Tinjauan Deskriptis. Yogyakarta: C.V Karyono, 2009. Cet, XIII.

Riddel, Peter G. "Menerjemahkan al-Qur'an ke dalam Bahasa-bahasa di Indonesia" dalam Henri Chambert-Loir (ed.), Sadur Sejarah Terjemahan di Indonesia dan Malaysia. Jakarta: KPG, 2009.

Riddel, Peter G. "Translating the Qur' an into Indonesian Languages," Al-Bayan, Journal of Qur'an and Hadith Studies, 12 (2014).

Rohmana, Jajang A. "Metrical Verse: As a Rule of Quranic Translation: Some 
Reflections on R.A.A. Wiranatakoesoema's Soerat Al-Baqarah (1888-1965).” $\begin{array}{lllll}\text { Al-Jami'ah } & 53, & \text { no. } & 2 & \text { (2015): }\end{array}$ https://doi.org/10.14421/ajis.2015.532.439-467.

. "Poetic Translation of the Qur'an in West Java Translation of the Qur'an in the Form of Sundanese Poetry Known as Guguritan." Suhuf 8, no. 2 (2015): 175-202. https://doi.org/10.22548/shf.v8i2.

- Terjemahan Puitis Al- Quran: Dangding Dan Pupujian Al- Quran Di Jawa Barat. Jawa Barat: Layung, 2019.

Rohmana, Jajang A. "Sastra Islam Nusantara: Puisi Guguritan Sunda Dalam Tradisi Sastra Islam Nusantara:" Akademika 21, no. 1 (2016): 1-18. https://www.researchgate.net/publication/340683983_Sastra_Islam_Nusantara Puisi_Guguritan_Sunda_Dalam_Tradisi_Keilmuan_Islam_Di_Jawa_Barat/link/ 5e992efe299bf13079a1 eafa/download.

—. "Sundanese Translations of the Qur'an in West Java: Characteristics and the Limits of Translation." DINIKA : Academic Journal of Islamic Studies 2, no. 2 (2017): 165-200. https://doi.org/10.22515/dinika.v4i2.1713.

Rohmana, Jajang A. dkk., Al-Qur'an, Bahasa Sunda, dan Moderasi: Dinamika Terjemah Al-Qur'an dan Bahasa Sunda 2018-2019. Jakarta: Litbangdiklat Press, 2020. Cet. I.

Rohmana, Jajang A. Memahami al-Qur'an dengan Kearifan Lokal: Nuansa Budaya Sunda dalam Tafsir al-Qur'an Berbahasa Sunda, dalam Qur'anic and Hadis Association Studies. Jakarta: UIN Press, 2013.

Rohmana, Jajang A. Sejarah Tafsir Al-Qur'an di Tatar Sunda. Bandung: Mujahid Press- Diktis Kemenag RI, 2014.

Rosidi, Ajip. Mencari Sosok Manusia Sunda. Bandung: Pustaka Jaya, 2010.

Saenong, Farid F. " Vernacularization of the Qur'an: Tantangan dan Prospek Tafsir Al-Qur'an di Indonesia", Interview dengan Prof. A. H. Johns, Jurnal Studi AlQur'an 1 no. 3, (2006).

Shaleh, Qomaruddin. dkk. Asbabun Nuzul: Latar Belakang Historis Turunnya Ayat-Ayat al-Qur'an. Bandung: CV. Dipenogoro, 1999.

Shihab, M. Quraish. Al-Qur'an dan Maknanya: Tarjamah Tafsiriyah, Memahami Makna al-Qur'an Lebih Mudah dan Cepat. Yogyakarta: Yayasan Ahlus Shuffah, 2011.

Shihab, M. Quraish. Tafsir al-Misbah: Pesan, Kesan, dan Keserasian al-Qur'an. Jakarta: Lentera Hati, 2007.

Suryalaga, R. Hidayat. Nadoman Nurul Hikmah: Tema-tema Ayat Al-Qur'an Daras 30. Bandung: Yayasan Nur Hidayah, 2010.

Suryalaga, R. Hidayat. "Ngamanfaatkeun Seni Budaya Sunda Pikeun Da'wah Islam", dalam Perhimpunan Keluarga Besar Pelajar Islam Indonesia (Perhimpunan KBPII), Ngamumule Budaya Sunda Nanjeurkeun Komara Agama. Bandung, Perhimpunan KBPII, 2006.

Suryalaga, R. Hidayat. Nadoman Nurul Hikmah: Tema-tema Ayat Al-Qur'an Daras 30. Bandung: Yayasan Nur Hidayah, 2003.

Suryalaga, R. Hidayat. Nur Hidayah, Saritilawah Basa Sunda Al-Qur'an Winangun Pupuh 30 Juz. cet. 2. Bandung: Yayasan Nur Hidayah, 2000,

Suryalaga, R. Hidayat. Nur Hidayah: Saritilawah Basa Sunda, Al-Qur'an 30 Juz Winangan Pupuh. Bandung: Yayasan Nur Hidayah, 1994 
266 The Vernacularity In The Tafsīinyah Translation Of Nadoman Nurul Hikmah - Ahmad Rifqi and Mariya

Wahid, Abdurrahman. Pergulatan Negara, Agama, dan Kebudayaan. Jakarta: Desantara, 2001.

Zimmer, Benjamin G. 'Al-'Arablryah and Basa Sunda: Ideologies of Translation and Interpretation among the Muslims of West Java." Studi Islamika 7, no. 3 (2000): 31-65.

Zuhdi, Nurdin. Pasaraya Tafsir Indonesia dari Kontestasi Metodologi hingga Kontektualisasi. Bantul: Kaukaba Dipantara, 2014. 